\title{
Stormwater Management Modelling for Ungauged Watershed in Matara Municipality
}

\section{H.M.D. Harshani and N.T.S. Wijesekera}

Most urban areas are having flood problems due to human activities. It is not easy to model urban watersheds since very often they are ungauged. This paper describes the modelling of an ungauged watershed in the Matara Municipal Council Area of Southern Sri Lanka using the free SWMM5 model of the EPA. Several field visits were conducted to capture the model parameters and flood scenario for model development and calibration. The watershed delineation was done using 1:10,000 topographic maps and canal slopes etc were determined using the elevation data of these maps. This watershed with an area of $1.12 \mathrm{~km}^{2}$ was modelled and calibration was done for the order of magnitude of the outputs. The model shows reasonable results with the actual conditions in the absence of gauge data This work demonstrates that urban stormwater model SWMM5 can be used in Matara Municipal Council area to a satisfactory level with adequate field data collection. However, for accurate results, it is necessary to suitably gauge the stream flows and carry out field and engineering surveys for the measurement of physical parameters. The model demonstrated the capability to identify engineering and stormwater management options. Model outputs revealed that cleaning of canals was one option for reducing the flooding at nodes. For the considered storm, a reduction of canal roughness from 0.2 to 0.015 reduced the flood peak by $56 \%$ and no flood is happening after introducing a rectangular detention unit which is having $200 \mathrm{~m}^{2}$ floor area.

Keywords: Urban, Stormwater, ungauged, Mathematical modelling, flooding, SWMM5

\section{Introduction}

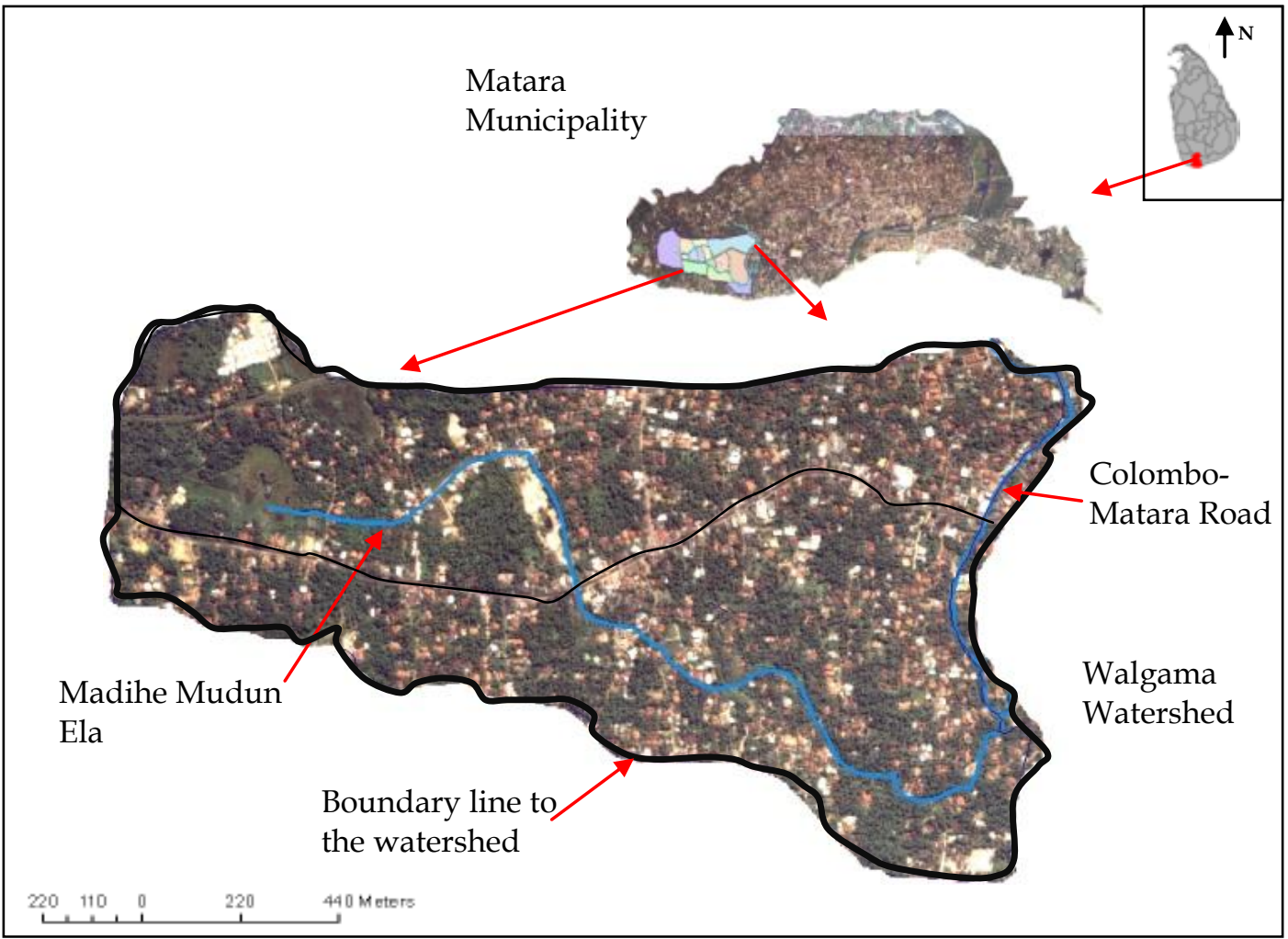

Figure 1 - Study Area

Today, an urban flood due to poor stormwater management is a major issue in most parts of the country. There are many flood prone urban
Miss. H.M.D. Harshani B.Sc. Eng. (Hons) (Moratuwa),

Eng. (Prof.) N.T.S.Wijesekera, B.Sc. Eng. (Sri Lanka), C. Eng., FIE(Sri Lanka), M. Eng. (Tokyo), D. Eng. (Tokyo), Senior Professor of Civil Engineering, Department of Civil Engineering, University of Moratuwa. Sri Lanka 
areas which are subjected to significant inundations several times a year. (Marsalek,J et al.2006.[4]).

Complaints indicate that many areas which had never flooded previously are now flooded mostly due to blockage of drainage paths and increase of impervious surfaces.

Several urban areas in the country have been experiencing flood problems due to lack of proper storm water management systems. Due to high impervious area, instead of infiltrating in to the soil almost all precipitated water becomes surface runoff and when there is no proper drainage systems most of the areas get inundated. This makes roads in the city to appear as waterways and leads to a sequence of problems. In urban areas, land owners fill their lands to prevent surface runoff getting into their lands; unauthorized constructions block the drainage paths and increasing impervious areas, are the main reasons which cause the stormwater drainage problems. (Polaskova et al 2005. [6], David, E et al. [3]).

Therefore it is very important to evaluate the causes for the stormwater drainage problem in urban areas in order to implement suitable management options as mitigatory actions.

For this study, Walgama area (Fig. 01.) of Matara Municipality which has been facing flood problems for many years was selected to investigate the stormwater drainage problem and an attempt was made to provide management options through computer based simulation modelling. EPA SWMM is a mathematical model which can be used to model stormwater in urban watersheds. But in Sri Lanka, It has not been used for ungauged small watersheds.

The EPA Storm Water Management Model (SWMM) is a dynamic rainfall runoff simulation model. It was developed in 1971 by the Water Resources Engineers, for the Environmental Protection Agency (EPA).(http://www.epa.gov/ednnrmr/model. [7]). Major input parameters for the model are rainfall and catchment parameters which include sub catchments, canals, junctions, rain gauge and outfalls.

Since there are no gauged urban water sheds in Sri Lanka, significant data was not available for model calibration and verification. However, Walgama watershed was selected for the mathematical modelling and data were collected through several field surveys. As SWMM can model several outfalls simultaneously and is capable of presenting outflows at canals and junctions with animations, finding management options were easy.

\section{Methodology}

The study methodology included a literature survey, field work for identification of input parameters, field observations for model calibration, modeling of the watershed, and a parameter sensitivity study to propose management options.

Literature survey was carried out on several published and unpublished studies about storm water management options, urban catchment handling, runoff calculation methods and available methods for storm water management. (Chouli.E. et al, 2005.[1]).

\subsection{Data Collection}

Since the study area is ungauged, there were no recorded data available. Therefore, field work was important for collecting the data for model development and calibration. Desk studies were carried out using satellite images and the $1: 10,000$ topographic maps of the survey department, in order to find out drainage directions, land use patterns and subcatchment slopes.

In order to model the actual field condition, as it is, all canal details and sub catchment details must be observed within the catchment area and data must be collected for each parameter. Several field visits were carried out to gather the information about the drainage network characteristics and flooding details. Since there were time and resource limitations, data were collected using linen tape and hand held GPS and at the same time eye estimations were used to estimate several parameters.

Subcatchment land use pattern, topography and vegetation types were observed during field visits and subcatchment slope, area and percentage of impervious areas were calculated using GIS tool. Vegetation type and percentage of impervious area are important to determine the Manning's Roughness Coefficient for over land flow. Typical Manning's roughness values were collected from some text books. (Chow, V. T. et al, 1998.[2], Maidment, D.R.,1993.[5]). Parameters of subcatchments are as in Table 01. Sub catchment number is related to the figure 03 and ' $N$ ' stands for Coefficient of Manning roughness. 
Table 1 - Subcatchment parameters

\begin{tabular}{|c|c|c|c|c|c|c|}
\hline \multicolumn{7}{|c|}{ Subcatchment properties } \\
\hline $\begin{array}{c}\text { Subcatchment } \\
\text { Number }\end{array}$ & Area & Width & $\begin{array}{c}\% \\
\text { slope }\end{array}$ & $\begin{array}{c}\% \\
\text { impervious }\end{array}$ & N -impervious & $\begin{array}{c}\text { N - } \\
\text { pervious }\end{array}$ \\
\hline 1 & 24.087 & 385 & 8.8 & 15 & 0.023 & 0.4 \\
\hline 2 & 5.814 & 305 & 7.27 & 20 & 0.024 & 0.15 \\
\hline 3 & 1.228 & 182 & 0.055 & 25 & 0.01 & 0.1 \\
\hline 4 & 2.918 & 220 & 0.5 & 30 & 0.01 & 0.1 \\
\hline 5 & 3.148 & 265 & 8.37 & 23 & 0.01 & 0.18 \\
\hline 6 & 2.728 & 260 & 0.5 & 25 & 0.01 & 0.1 \\
\hline 7 & 2.912 & 277 & 0.325 & 25 & 0.01 & 0.1 \\
\hline 8 & 1.397 & 200 & 0.05 & 35 & 0.01 & 0.1 \\
\hline 9 & 9.028 & 490 & 3.45 & 10 & 0.01 & 0.2 \\
\hline 10 & 7.647 & 300 & 0.46 & 25 & 0.01 & 0.1 \\
\hline 11 & 7.012 & 360 & 0.687 & 23 & 0.01 & 0.1 \\
\hline 12 & 6.889 & 236 & 0.1 & 20 & 0.01 & 0.1 \\
\hline 13 & 16.659 & 535 & 0.131 & 39 & 0.01 & 0.1 \\
\hline 14 & 20.731 & 500 & 0.18 & 30 & 0.01 & 0.17 \\
\hline
\end{tabular}

Madihe Mudun Ela is the main canal section of the Walgama watershed. Canal geometry, vegetation along the canal, bed slope, bed condition and canal lengths were observed during the field visits and GPS locations were recorded at each junction as it is important for the calculation of elevation at the junction. Some canal parameters are as given in Table 02 . Geological features of each parameter were collected from digital photographs as they are useful in model verification.
A flood survey was carried out to collect past flood information from stakeholders with the aid of a questionnaire developed for this study. The public, in the watershed, provided their memories in flood events of the recent past which had occurred on $18^{\text {th }}$ of July 2008. It was revealed that the upstream of Madihe Mudun Ela canal undergoes a flood, even after a small rainfall. Flood heights indicated by them are shown in Table 03 and ponded areas at each junction are indicated in Figure 04 and their flow directions were observed and noted during the field visits.

Table 2 - Collected Data from Field Surveys

\begin{tabular}{|c|c|c|c|c|c|c|}
\hline \multirow[b]{2}{*}{ Chainage } & \multicolumn{3}{|c|}{ Canal Geometry } & \multicolumn{3}{|c|}{ Surface cover } \\
\hline & shape & $\begin{array}{l}\text { Top } \\
\text { width }(\mathrm{m})\end{array}$ & $\begin{array}{l}\text { Maximum } \\
\operatorname{depth}(\mathrm{m})\end{array}$ & Left Bank & Right Bank & Bed \\
\hline $115 \mathrm{~m}$ & \multirow{9}{*}{ 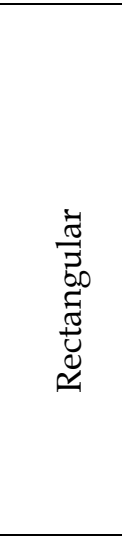 } & 3 & 1.6 & Vegetation & Vegetation & Clay \\
\hline $4.7 \mathrm{~m}$ & & 1.45 & 0.75 & Concrete & Concrete & Concrete \\
\hline $151.8 \mathrm{~m}$ & & 2.5 & 0.8 & Vegetation & Vegetation & Clay \\
\hline $20 \mathrm{~m}$ & & 1 & 0.8 & Concrete & Concrete & Concrete \\
\hline $33 \mathrm{~m}$ & & 2 & 0.6 & Concrete & Concrete & Concrete \\
\hline $80 \mathrm{~m}$ & & 2 & 0.75 & Gabian & Gabian & Muddy \\
\hline $55 \mathrm{~m}$ & & 2 & 0.8 & Gabian & Gabian & Muddy \\
\hline $15 \mathrm{~m}$ & & 0.9 & 0.4 & Vegetation & Vegetation & Vegetation \\
\hline $20 \mathrm{~m}$ & & 2 & 0.75 & Concrete & Concrete & Concrete \\
\hline
\end{tabular}


Table 3 - Past Flood Heights indicated by the stake holders

\begin{tabular}{|c|c|}
\hline Junction & Flood height $(\mathrm{m})$ \\
\hline $\mathrm{J} 1$ & 1.219 \\
\hline $\mathrm{J} 3$ & 0.762 \\
\hline $\mathrm{J} 4$ & 0.305 \\
\hline $\mathrm{J} 5$ & 0.152 \\
\hline $\mathrm{J} 6$ & 0.305 \\
\hline
\end{tabular}

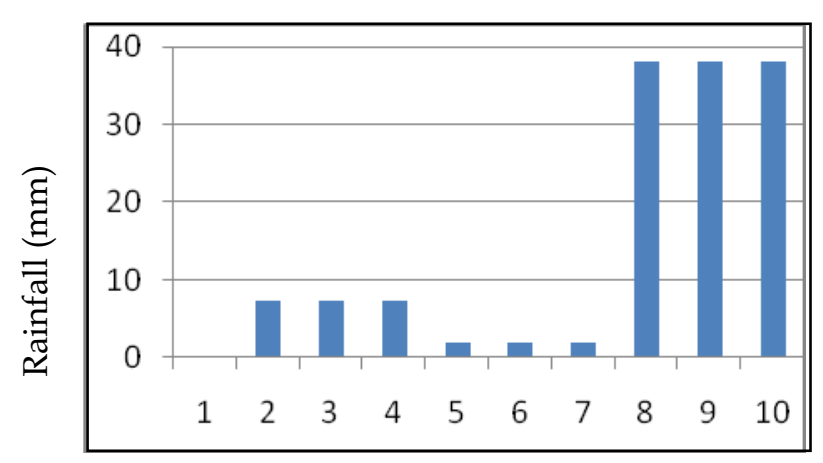

Time (months)

Figure 2 - Distribution of Rainfall
Rainfall data of the event of $18^{\text {th }}$ July 2008, which had been recorded at three hour intervals, were collected from the Irrigation Department at Matara because the flooded information collected from the field were pertaining to this event. As in Figure 02, time series was developed assuming uniform rainfall over three hour periods.

\subsection{Model Development}

The Watershed was delineated on 1:10000 topo sheets and then major sub catchments were drawn. These were used to develop the watershed schematic as in Figure 03 and a SWMM model was developed. Collected data were used to generate flood situation for a known rainfall event. According to the terrain, fourteen sub catchments having a slope between $8.8 \%-0.2 \%$ and an area between $0.05 \mathrm{~km}^{2}-0.3 \mathrm{~km}^{2}$ area variations were identified.

A canal was modelled using fourteen junctions as indicated in Figure 03. Due to lack of data, each canal section was assumed to be rectangular and has the same roughness value. The dynamic behaviour of water was simulated by allowing ponding at each junction.

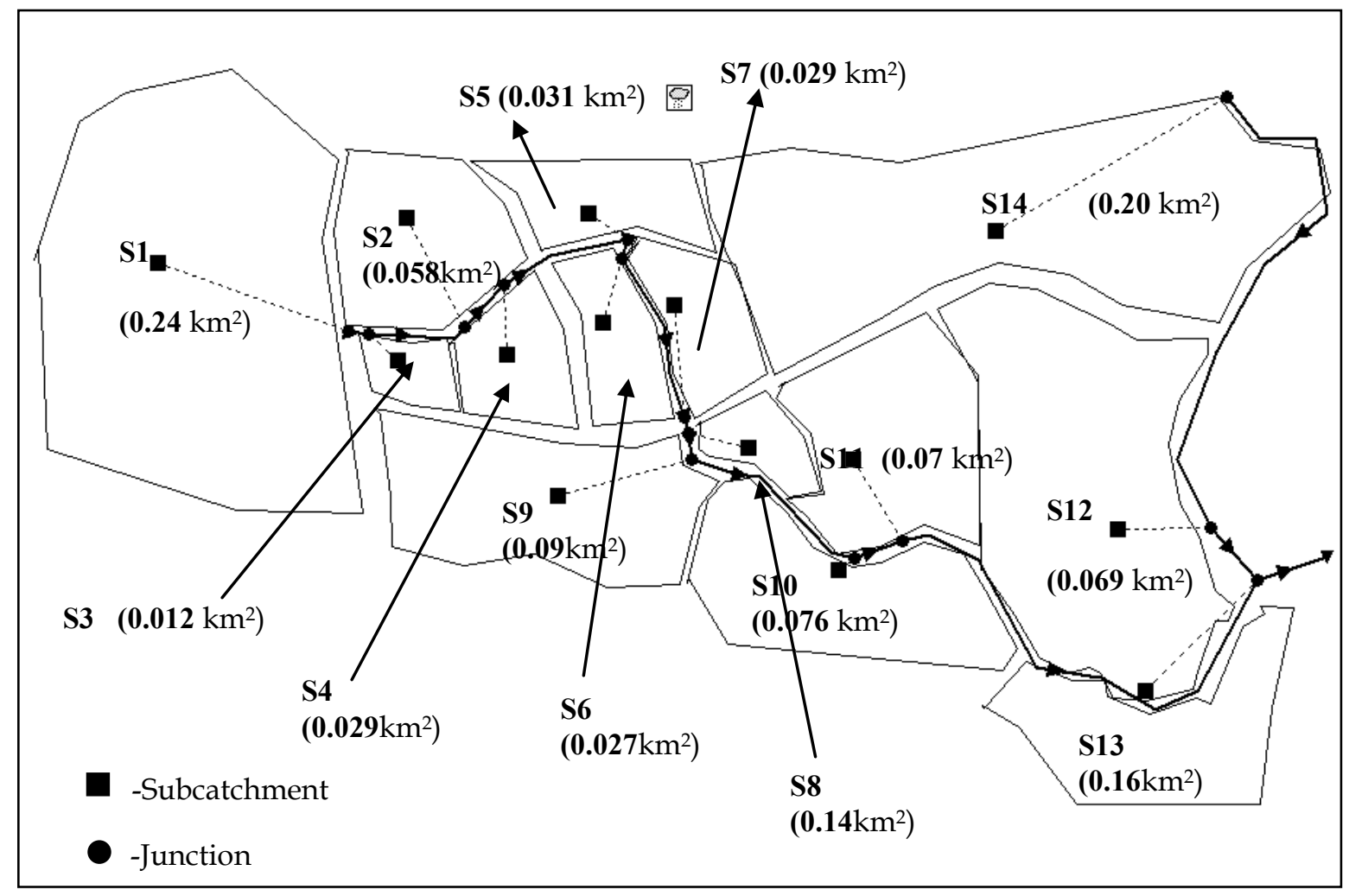

Figure 3 - Schematic Diagram of the Watershed 
Table 4 - Model Calibration Data

\begin{tabular}{|c|c|c|c|c|}
\hline Node & $\begin{array}{c}\text { Stake Holder's } \\
\text { Flood Height(m) }\end{array}$ & $\begin{array}{c}\text { Flood Volume Given } \\
\text { by Model }\left(\mathrm{m}^{3}\right)\end{array}$ & $\begin{array}{c}\text { Estimated Ponded } \\
\text { Area }\left(\mathrm{m}^{2}\right)\end{array}$ & $\begin{array}{c}\text { Flood Height } \\
\text { from Model(m) }\end{array}$ \\
\hline J1 & 1.219 & 28109 & 22500 & 1.243 \\
\hline J3 & 0.762 & 7983 & 40000 & 0.792 \\
\hline J4 & 0.305 & 1280 & 2500 & 0.32 \\
\hline J5 & 0.152 & 0 & 10000 & 0.518 \\
\hline J6 & 0.305 & 5364 & & 0 \\
\hline
\end{tabular}

Due to the limitation of time and resources, the ponding areas at each junction were calculated by observations. Using stakeholder information about ponding area, each area was averaged as reservoirs with an averaged rectangular base to compute the flood heights from the model calculated flood volumes. Results are shown the Table 04 .

\subsection{Model calibration}

The developed model was calibrated using flood locations and flood heights that were collected from the stakeholders (Table 03). A set of input parameters obtained from literature and compatible with the field conditions were used to develop the model and the outputs were observed. Since the model only provides the flood quantity of a particular node as a volume the conversions to heights was done as described earlier.

Due to limited actual flood data availability the calibration was limited to this single event.

According to the junction flooding summary from SWMM5, the junctions J1,J3, J4 and J6 were found as critical junctions that were significantly flooded. Comparison of the modelled flood heights and stakeholder flood heights are indicated in Table 04.

Since the model gives approximate flood heights with the stake holder's data, it can be decided that this model can be applied for modelling of urban watersheds.

After the model development, the sensitivity of the parameters was checked by changing canal roughness, subcatchment slope, manning roughness values within reasonable limits.

\section{Option Identification}

It is essential to provide some suitable options for this stormwater problem in this Walgama area as it severely affected the human day-today life. But, we have to consider an option that would incur a low cost as well as the ability to mitigate the current problem.

Since most of the canals were silted and vegetated, obstruction for the flow of water is high and, as a result, the Manning's roughness value taken for each canal was very high. As a solution, removing vegetation from the canal with proper maintenance was considered as an option. The model outputs were observed for this scenario. The key options considered for the system are shown in the last column of Table 05. According to the results, concreting the canal and increasing the depth of the canal will not bring about a significant flood reduction.

At the same time, improving detention capacity was also identified as an effective way to attenuate peak flow in the catchment. A marshy land at the beginning of the canal was observed and this was targeted as detention storage. Increasing of canal depth, concreting canals were some other options that are considered in this study.

Table 05 indicates the actual flood quantity and quantity of flood reduction for each option available. A reduction of Canal roughness from 0.2 to 0.015 reduced the flood peak by $56 \%$. After the introduction of a rectangular detention unit with a floor area of $200 \mathrm{~m}^{2}$ at the junction J1 together with the reduction of canal roughness in the entire canal network, the flooding status of the project area change to zero flooding at all nodes. The water surface profile for this situation for the calculated rainfall event is shown in Figure 04. 
Table 5 - Comparison of Available Options

\begin{tabular}{|c|c|c|c|}
\hline Condition & $\begin{array}{l}\text { System } \\
\text { flooding } \\
\left(\mathrm{m}^{3}\right)\end{array}$ & $\begin{array}{c}\text { Flood } \\
\text { quantity } \\
\text { reduction } \%\end{array}$ & Action \\
\hline $\begin{array}{l}\text { Present situation as } \\
\text { identified in the field }\end{array}$ & 41458 & & $\begin{array}{l}\text { Average canal depth } 1.8 \mathrm{~m} \text {, canal roughness } \\
0.02\end{array}$ \\
\hline $\begin{array}{l}\text { Remove vegetation of the } \\
\text { canals }\end{array}$ & 18132 & 56 & $\begin{array}{l}\text { canal roughness }(\mathrm{N}) \text { reduced from } 0.02 \text { to } \\
\text { upto } 0.025\end{array}$ \\
\hline Concrete all canals & 17397 & 58 & $\begin{array}{l}\text { canal roughness }(\mathrm{N}) \text { reduced from } 0.02 \text { uptc } \\
0.015\end{array}$ \\
\hline $\begin{array}{l}\text { Manings ' } n \text { ' changed and } \\
\text { with a canal depth increase }\end{array}$ & 16882 & 59 & $\begin{array}{l}\text { canal roughness }(\mathrm{N}) \text { reduced from } 0.02 \text { uptc } \\
0.015 \text {, Canal depth increasd up to } 1.25 \mathrm{~m}\end{array}$ \\
\hline $\begin{array}{l}\text { Manings ' } n \text { ' changed \& } \\
\text { introduction of a } \\
\text { storage unit }\end{array}$ & $\begin{array}{c}\text { No } \\
\text { flooding }\end{array}$ & 100 & $\begin{array}{l}\text { Add a rectangular storage unit at junction } \\
\mathrm{J} 1 \text { having a flood area of } 200 \mathrm{~m}^{2}\end{array}$ \\
\hline
\end{tabular}

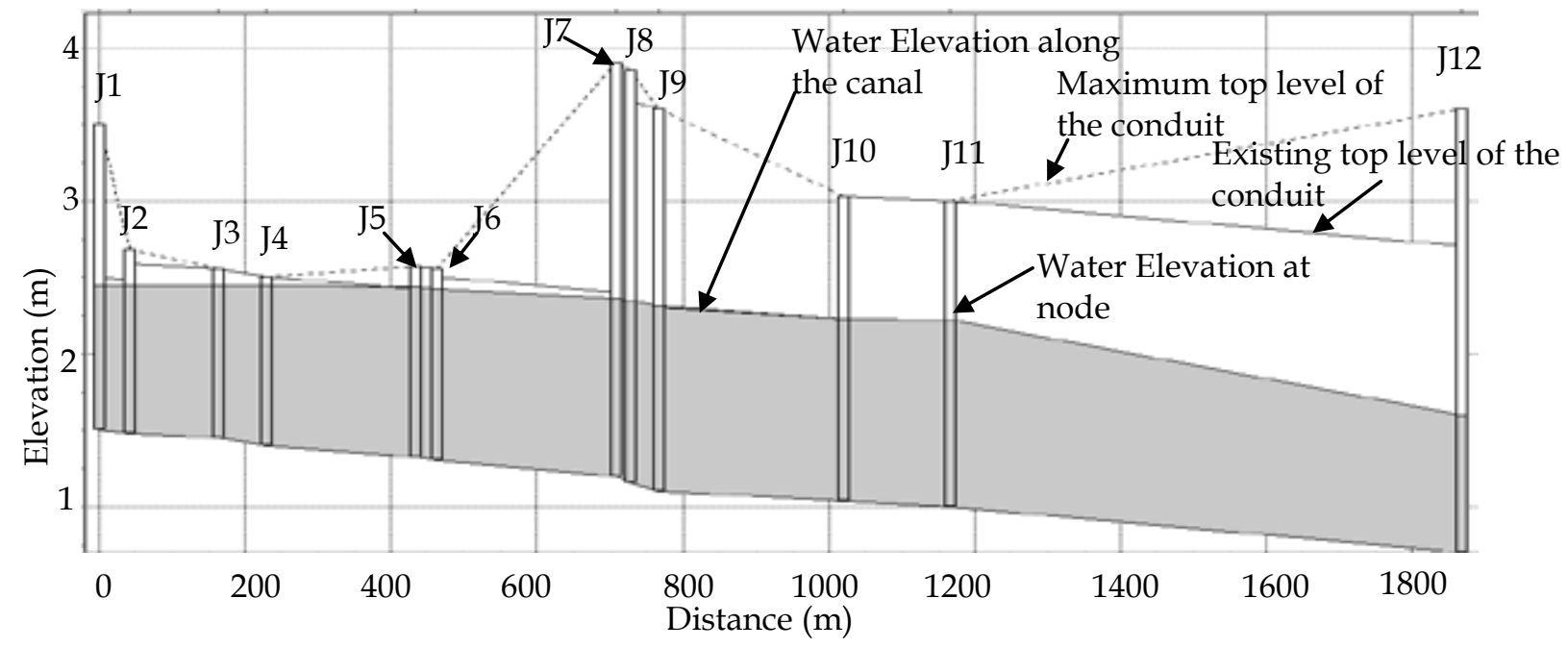

Figure 4 - Water Elevation Profile along the Canal

\section{Discussion}

This study demonstrates the capability of mathematical modeling of ungauged watershed to evaluate the stormwater problems. Matching of model outputs and the field data was reasonable considering the data limitations and it could be identified that more spatially and temporally detailed field data could produce better results. In the modelling no tidal effect was considered and the computations assumed free flow conditions. This is a limitation in the computations. However the present work revealed the successful development of a mathematical stormwater model for the project area.

Applying storm water models for urban areas having flat terrain and many human interventions is a challenge when it is ungauged because such situations require finer spatial and temporal resolutions in parameter values and also in the flow quantities. Since the urban areas are dynamic, it is difficult to get the updated values for parameters like land cover changes if proper gauging and frequent data collections are not carried out. The present modelling shows that in the absence of detailed field data, the next best option of collecting reasonable field data would provide solutions that could be proposed with engineering judgements leading to delivering parameter ranges that enable identification of problem areas and trying out a variety of options.

The usage of stormwater models for various canal and catchment conditions, parameters required by the model, procedure of measuring parameters in the field for results verification in the absence of gauged data were some of the 
critical situations that were faced during the study. To overcome the data scarce situation, the present work carried out an in-depth study of the modelling concepts to identify the parameter values that could be measured in the field for use either as base data or to make judgements over standard guideline recommendations. Also in the present work a demonstration was made that assessment of stakeholder information could be wisely used for model calibration. Though it is common for modellers to wait for base data, this type of approximate modelling can be initiated as the first step and then strengthen the results with a more focussed data collection and a follow up modelling programme. This work also presented that the potential of SWMM5 to produce the dynamic flow behaviour can also be effectively used for engineering advantage. In the present work, assessment of model outputs with parameter variations recognised that it is necessary to be careful about the following to arrive at more reliable outputs.

1. Variation of canal section and roughness values along the canal.

2. Identification of base data for model calibration and verification

3. Maps at a resolution of better than 1:10,000 scales or with elevation data at a higher spatial resolution.

4. Planning of field data collection programms and recognition of base data requirements prior to visits.

5. Tidal action must be taken into account during modelling of coastal watersheds.

\section{Conclusions}

Major conclusions of this study can be summarized as follows.

1. SWMM 5 can be used to simulate the ungauged urban catchments which have to be studied considering the dynamic nature of human influences. However, for very specific and accurate results from the model, then, it is necessary to initiate comprehensive data collection programmes.

2. The most sensitive parameter for the out flow is canal roughness and reducing the value from 0.02 to 0.015 caused a $56 \%$ reduction in the flood peak.
3. If an option of detention storage is provided together with canal cleaning, achieving a Manning's roughness coefficient of 0.015 indicated that $100 \%$ flood reduction can be achieved for the considered storm.

4. Increasing of canal depth and concreting of the canal with a roughness value of 0.015 resulted in only a $1 \%$ reduction of flood peak value.

\section{References}

1. Chouli. E, Aftias, E \& Deutsch, J.C, Applying Storm Water Management in Greek Cities: learning from the European Experience, Science Direct, Faculty of Civil Engineering, National Technical University of Athens, 2005.

2. Chow, V. T., Maidment, D. R. \& Mays, L. W. Applied Hydrology, New York etc., McGraw-Hill. (0-07-010810-2),1998.

3. David, E, Farley.J \& Haynes, C, Design and Routing of Storm Flows in an Urbanized Watershed without Surface Streams, Journal of Hydrology, Department of Civil and Environmental Engineering, Duke University USA.

4. Marsalek,J, -CisnerosB.E.J, Karamouz,A \& Chocat.B, Urban Water Cycle Processes and Interactions, International Hydrological Programme, Technical Documents in Hydrology, No. 78,UNESCO, 2006.

5. Maidment, D.R., Hand Book of Hydrology. $1^{\text {st }}$ ed. New York: McGraw Hill Book Company, 1993.

6. Polaskava K., Hlavinek P., Haloan R., Integrated Approach for Protection of an Urban Catchment Area. Institute of Municipal Water Management, Brno University of Technology, 2005.

7. http://www.epa.gov/ednnrmrl/models/s wmm/index.htm Visited 23 $3^{\text {rd }}$ December 2009. 
